\title{
Incidence of Metoclopramide-induced Methemoglobinemia
}

\author{
Metoklopramide Bağlı Methemoglobinemi İnsidansı
}

\author{
Emine AKINCI, Yücel YÜZBAŞIOĞLU, Semra ASLAY, Figen COŞKUN \\ Department of Emergency Medicine, Ankara Training and Research Hospital, Ankara, Turkey
}

\begin{abstract}
SUMMARY
\section{Objectives}

Methemoglobinemia could be a congenital or acquired condition. It causes clinical conditions ranging from simple cyanosis to hypoxia, lactic acidosis and death. Several cases of metoclopramide-induced methemoglobinemia both in infants and adults have been reported in literature. We aimed to investigate the incidence of metoclopramideinduced methemoglobinemia in our emergency department (ED).
\end{abstract}

\section{Methods}

Adult patients who were admitted to the ED with renal colic, peripheral vertigo, acute gastroentiritis and vascular headache and who were given a single dose of $10 \mathrm{mg}$ metoclopramide for nausea and/or vomiting were involved in the study. The total number of study sample was 270 .

\section{Results}

Of the 270 patients, 208 (77\%) were female and 62 (33\%) were male. Patients' methemoglobin levels ranged between $0.5-5.20 \mathrm{gr} /$ $\mathrm{dl}$ with an average value of $0.97 \mathrm{gr} / \mathrm{dl}$. There has been no significant difference found between methemoglobin levels and patients' diagnoses, sex, age, comorbid diseases, and medications taken for comorbid factors.

\section{Conclusions}

Although rarely seen, possibility of development of metoclopramide-induced methemoglobinemia following metoclopramide administration should be kept in mind.

Key words: Emergency department; methemoglobinemia; metoclopramide.

\section{ÖZET}

Amaç

Methemoglobinemi konjenital veya edinsel olarak görülür. Basit siyanozdan, hipoksi, laktik asidoz, koma ve ölüm gibi klinik tablolara neden olabilir. Literatürde gerek infant gerekse erişkinlerde metoklopramide bağlı birkaç methemoglobinemi olgusu bildirilmiştir Bu yüzden sıklıkla kullandığımız bir ilaç olan metoklopramide bağIı methemoglobinemi insidansını araştırmayı amaçladık.

\section{Gereç ve Yöntem}

Ankara Eğitim ve Araştırma Hastanesi Acil Servisi'ne başvuran 270 hasta çalışmaya dâhil edildi. Renal kolik, periferik vertigo, akut gastroenterit (AGE) ve vasküler tip baş ağrısı tanısı alıp bulantı ve/veya kusması için tek doz $10 \mathrm{mg}$ metoklopramid yapılan erişkin hastalar çalışmaya alındı.

\section{Bulgular}

Hastaların \%77'si kadın \%33'ü erkekti. Hastaların ortalama hemoglobin düzeyleri 10.3-15.6 gr/dl arasında iken methemoglobin düzeyleri ise 0.5-5.20 gr/dl arasında olup ortalama değer $0.97 \mathrm{gr} / \mathrm{dl}$ olarak çıktı. Hastaların acil serviste aldığı tanılara, cinsiyete, yaş gruplarına, komorbid hastalıklara ve komorbid hastalık nedeniyle ilaç kullanımına göre methemoglobinemi düzeyleri açısından herhangi bir farklılık bulunamadı.

\section{Sonuç}

Metoclopramide uygulanması sonrasında nadir de olsa erken dönemde methemoglobinemi gelişebileceği unutulmamalıdır.

Anahtar sözcükler: Acil servis; methemoglobinemi; metoclopramide. 


\section{Introduction}

Methemoglobinemia is a condition in which the iron in the hemoglobin is oxidized from the ferrous $\left(\mathrm{Fe}^{2+}\right)$ state to the ferric $\left(\mathrm{Fe}^{3+}\right)$ state. ${ }^{[1]}$ Severe methemoglobinemia alters the oxygen and carbondioxide carrying capacity of blood, resulting in hypoxia, lactic acidosis and death. Methemoglobinemia can be a congenital or acquired condition. Various chemicals and drugs, including nitrates, chlorates, phenytoin, and local anesthetics, have been reported to cause acquired methemoglobinemia. ${ }^{[2]}$

Metoclopramide is a centrally active anti-emetic. It is frequently used in EDs for patients complaining of nausea and vomiting. Several cases of metoclopramide-induced methemoglobinemia in infants and adults have been reported in literature. We aimed to investigate the incidence of metoclopramide-induced methemoglobinemia in our ED.

\section{Materials and Methods}

This prospective study included 270 adult patients who presented to the Ankara Training and Research Hospital ED between January and March 2010 and who agreed to participate in the study. All the patients were diagnosed with one of the following conditions: renal colic, peripheral vertigo, acute gastroenteritis and vascular headache were involved in the study. They were given a single dose of $10 \mathrm{mg}$ (standard treatment dose) IV metoclopramide for their nausea and/or vomiting and their venous blood gas samples were obtained one hour after the administration of metoclopramide. Blood samples were collected in $2.5 \mathrm{ml}$ tubes which were treated with 150 IU lithium heparin and analyzed in the emergency labaratory using Roche Cobas 221 devices. This patient group had not received any other medication apart from metoclopramide prior to their blood samples being collected. We excluded patients who had received metoclopramide, nitrates, phenytoin, local anesthetics for any reason within one week prior to their ED visit.

Treatment of patients with methemoglobinemia was planned to administration nasal oxygen, IV dextrose and IV methylene blue if necessary.

Following our encounter with a patient who developed methemoglobinemia following metoclopramide administration in our ED and after we found similar cases reported in the literature we decided to undertake the study detailed in this article. Permission was obtained from Ankara Training and Research Hospital Ethics Board prior to the study.

\section{Statistical Analysis}

The statistical analysis was performed using SPSS ver. 16.0. Descriptive statistics for continuous variables as mean \pm standard deviation or median (minimum-maximum) as the nominal variables and the number of cases (\%) as shown. The Kruskal-Wallis test was used for comparison of groups. Differences found significant were analyzed using the MannWhitney U-test. A p-value of $<0.05$ was considered significant. A p-value of $<0.05$ was considered significant.

\section{Results}

Of the 270 patients, 208 (77\%) were female and 62 (33\%) were male. Average age was $40.8 \pm 14.0$ (18 to 83 years). The patients' initial vital signs were all within normal limits. Twenty nine (10.7\%) patients were diagnosed with renal colic, 59 (21.9\%) with peripheral vertigo, 29 (10.7\%) with acute gastroenteritis, and 153 (56.7\%) with vascular type headache (Table 1). 208 (77\%) patients did not have relevant medical history, whereas 62 (33\%) patients had diabetes and/or hypertension and were taking one or more medicines for their conditions.

The patients' average hemoglobin levels ranged between 10.3-15.6 gr/dl, while their methemoglobin levels ranged between $0.5-5.20 \mathrm{gr} / \mathrm{dl}$ with an average value of $0.97 \mathrm{gr} / \mathrm{dl}$ (Table 2). No significant relationship was found between the patients level of methemoglobin and their age groups, sex, comorbid diseases, medications taken for comorbid factors and diagnosed conditions (Table 3). Only one male (patient

Table 1. Patients' initial diagnoses

\begin{tabular}{lcc}
\hline & Frequency & Percent \\
Renal colic & 29 & 10.7 \\
Vertigo & 59 & 21.9 \\
Akut gastroenteritis & 29 & 10.7 \\
Vascular headache & 153 & 56.7 \\
Total & 270 & 100.0
\end{tabular}

Table 2. Hemoglobin and methemoglobin levels

\begin{tabular}{lccccc}
\hline & Mean & Standard deviation & Median & Minimum & Maximum \\
Hemoglobin $(\mathrm{gr} / \mathrm{dl})$ & 12.1 & 10.500 & 12 & 10.3 & 15.6 \\
Methemoglobin $(\mathrm{gr} / \mathrm{dl})$ & 0.9700 & 0.36044 & 0.9000 & 0.50 & 5.20
\end{tabular}


Table 3. Methemoglobin levels based on age groups, sex, medication use, comorbid disease, and diagnoses

\begin{tabular}{|c|c|c|c|c|c|}
\hline & No of Cases & Median & Minimum & Maximum & $\mathbf{p}$ \\
\hline Age Groups (years) & & & & & 0.614 \\
\hline$\leq 20$ & 14 & 0.95 & 0.8 & 1.5 & \\
\hline $21-30$ & 52 & 0.9 & 0.6 & 2.0 & \\
\hline $31-40$ & 74 & 0.9 & 0.6 & 1.9 & \\
\hline $41-50$ & 70 & 0.9 & 0.5 & 2.3 & \\
\hline $51-60$ & 33 & 0.9 & 0.5 & 1.8 & \\
\hline $61-70$ & 16 & 0.9 & 0.7 & 1.8 & \\
\hline$>70$ & 11 & 0.9 & 0.6 & 5.2 & \\
\hline Sex & & & & & 0.506 \\
\hline Male & 62 & 0.9 & 0.5 & 5.2 & \\
\hline Female & 208 & 0.9 & 0.5 & 2.3 & \\
\hline On medication & & & & & 0.667 \\
\hline Yes & 47 & 0.9 & 0.6 & 5.2 & \\
\hline No & 223 & 0.9 & 0.5 & 2.3 & \\
\hline Comorbid disease & & & & & 0.719 \\
\hline Exist & 208 & 0.9 & 0.5 & 5.2 & \\
\hline Does not exist & 62 & 0.9 & 0.6 & 2.3 & \\
\hline Diagnose & & & & & 0.359 \\
\hline Renal colic & 29 & 0.9 & 0.5 & 2.3 & \\
\hline Vertigo & 59 & 0.9 & 0.5 & 1.9 & \\
\hline Gastroenteritis & 29 & 1 & 0.7 & 1.3 & \\
\hline Headache & 153 & 0.9 & 0.5 & 5.2 & \\
\hline
\end{tabular}

A), with history of hypertension and was taking medication had a methemoglobin level of $5.20 \mathrm{gr} / \mathrm{dl}$. This patient received supplemental oxygen at 6 liters per minute and a total of 1,000 cc of D5W solution was administered. The patient did not develop any clinical symptoms as his methemoglobin level was not critically elevated. He was placed in observation unit and follow-up laboratory examinations were continued as he received above therapy. His methemoglobin levels was $3.1 \mathrm{gr} / \mathrm{dl}$ after 3 hours and was $0.8 \mathrm{gr} / \mathrm{dl}$ after 6 hours. The patient was discharged after 6 hours since no additional abnormalities detected in his condition.

\section{Discussion}

Hemoglobin is a molecule that is mainly found in erythrocytesand carries oxygen to the tissues. In order to be able to do this, the iron in its structure needs to be in the ferrous $\left(\mathrm{Fe}^{2+}\right)$ state. Methemoglobinemia is a condition in which the iron within hemoglobin is oxidized as a result of certain oxidative stressors and is changed from the ferrous $\left(\mathrm{Fe}^{2+}\right)$ to the ferric $\left(\mathrm{Fe}^{3+}\right)$ state. Since methemoglobin can not transport oxygen this shifts the oxygen-hemoglobin dissocia- tion curve to the left and results in difficulties in delivering oxygen to the tissues. ${ }^{[1-4]}$ Under normal physiological conditions, the methemoglobin level will not exceed $2-3 \%$ of the total hemoglobin. ${ }^{[5]}$ In acute cases increases up to $20-30 \%$ in methemoglobin levels are tolerated well in patients without anemia, however, an increase to $70 \%$ or more is typically fatal. ${ }^{[6]}$ Blue-gray cyanosis unresponsive to oxygen therapy is a valuable finding.

Most cases of methemoglobinemia are developed due to the excessive production of methemoglobin following exposure to oxidant drugs, chemicals, or toxins such as nitrites, nitrates, chlorates, kinins, aminobenzens, nitrobenzens, nitrotoluenes, phenacetine, chloroquine, dapsone, phenytoin, sulphanomides and local anesthesics. ${ }^{[2,7]}$ In the literature there are many case reports regarding methemoglobinemia caused by the administration of local anesthetics via the topical and injection route.

The treatment of methemoglobinemia includes administering supplemental oxygen, dextrose and methylene blue. The administration of dextrose is thought to increase the production of nicotinamide adenine dinucleotide (NADH) 
via glycosis which increases the clearance of patient's methemoglobin through NADH diaphorase enzyme. ${ }^{[8]}$ Patients with chronically mild increases in methemoglobin level may be completely asymptomatic and require no specific therapy. Patients with mild chronic methemoglobinemia due to enzyme deficiencies can be treated with oral medications in an attempt to decrease cyanosis. These medications include methylene blue, ascorbic acid, and riboflavin. ${ }^{[1]}$

Metoclopramide is a centrally active antiemetic which inhibits the central and peripheral effects of apomorphine. The pharmacological effects of metoclopramide are seen within 30-60 minutes in oral route, 1-3 minutes in IV route and 1015 minutes following IM route. With the effects typically lasting from 1 to 2 hours. Eighty percent of metoclopramide is excreted in the urine unchanged or in a conjugated form.

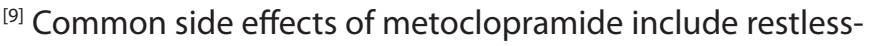
ness, drowsiness, fatigue and tiredness. Infrequent side effects include insomnia, headache, nausea, diarrhea/constipation and extrapyramidal reactions. ${ }^{[10]}$ Metoclopramide is also known to cause methemoglobinemia in newborn and premature babies. ${ }^{[11-13]}$ Mérieau et al. reported methemoglobinemia in 5 day-old newborn and Kearns et al. reported another case in 3 week-old infant. ${ }^{[14,15]}$ It is thought that the metabolities of metoclopramide, which is excreted through renal system, causes methemoglobinemia. Newborn and premature babies are more susceptible to this condition because of their underdeveloped renal functions.

Karadsheh et al. ${ }^{[16]}$ reported a pediatric case in which methemoglobinemia developed after 28 hours following the IV administration of $10 \mathrm{mg}$ metoclopramide. This patient was reported to have glucose-6-phosphate dehydrogenase deficiency as well as NADH cytochrome B5 reductase deficiency. Since in our study patient a experienced methemoglobinemia shortly after the IV administration of metoclopramide. We, therefore, collected blood samples one hour after the administration of $10 \mathrm{mg}$ metoclopramide from all the patients in our study group. Only patient in our study had a methemoglobin level $5.20 \mathrm{gr} / \mathrm{dl}$ with a hemoglobin level of $11.2 \mathrm{gr} / \mathrm{dl}$. This particular case was complaining of difficulty breathing without any other clinical finding. The patient was treated with 8 Ipm oxygen via nasal cannula and 5\% IV dextrose. Detxrose is known to raise NADH production via glycolysis, which, in turn helps methemoglobin clerance through NADH diaphorase enzyme. ${ }^{[5]}$ According to the literature, methemoglobin levels gradually decrease at the rate of about 0.15 percentage points per hour. ${ }^{[3]}$ This patient had methemoglobin levels brought down to $3 \mathrm{gr} / \mathrm{dl}$ after 4 hours upon presentation and down to $0.8 \mathrm{gr} / \mathrm{dl}$ after 12 hours in the ED. None of the remaining patients in the study had a high level of methemoglobin. We believe is due to fact that methemoglobinemia is an uncommon complication. How- ever, there are a number of methemoglobinemia cases in the literature including adult patients. Grant et al. ${ }^{[17]}$ reported a 23 year old patient who developed methemoglobinemia following oral intake, whereas Mary et al. ${ }^{[18]}$ reported a post-operative adult case following administration of multiple IV doses of metoclopramide. Repetitive administration of metoclopramide could be seen as a risk factor for the development of methemoglobinemia. This study investigated the incidence of methemoglobinemia after a single dose metoclopramide administration, which is the first study in the medical literature.

Further studies are needed to determine the methemoglobinemia incidence following repetitive administration of metoclopramide.

\section{Limitations}

For the study sample only the methemoglobin levels were analysed from blood samples after one hour after the administration of metoclopramide in our study group. Repeating laboratory studies in regular intervals for a longer period of time could be more meaningful. However, implementing the study in a high volume ED, with daily visits ranging from 600 to 800, prevented us from monitoring the sample group of patients over a longer time period. We did not collect data during the entire year, since it was felt that seasonal changes do not effect the incidence of methemoglobinemia in a population. Methemoglobin levels was not requested in patients before the administration metoclopromide. However, we did not want to whether patients with symptoms suggestive of methemoglobinemia. Failure to work on this issue, and the incidence of previously unknown to compute the number of patients. But we did not to determine a sample size in this study.

\section{Conclusion}

According to the results of this study, we conclude that the methemoglobinemia is rarely seen after the implementation of metoclopramide. Administration of a single dose of metoclopramide for the treatment of indicated conditions in the emergency department to be reliable, but the possibility of development of methemoglobinemia resulting from this therapy should still be kept in mind.

\section{Conflict of Interest}

The authors declare that there is no actual or potential conflict of interest.

\section{References}

1. Michelle, Kumar M. Methemoglobinemia over view e Medicine from Web med. Available from: http://www.emedicine. medscape.com/article/956528-overview. [cited in 2010]. 
2. Osterhoudt KC. Methemoglobinemia. In: Ford M, Delaney K, Ling L, Ford ET, editors. Clinical toxicology. 1st ed., Philadelphia: W. B. Saunders Company; 2001. p. 211-7.

3. Tobias JD, Ramachandran V. Intraoperative diagnosis of unsuspected methemoglobinemia due to low pulse oximetry values. J Int Care Med 2009;24:273.

4. Dutta R, Dube SK, Mishra LD, Singh AP. Acute methemglobinemia. Internet J Emerg Intensive Care Med 2008;11:10924051.

5. Jaffe ER. Methemoglobinemia in the differential diagnosis of cyanosis. Hosp Pract 1985;15:92-110.

6. Coleman MD, Coleman NA. Drug-induced methaemoglobinemia. Drug Safety 1996;14:394-405.

7. Saxena H, Prakash Saxena A. Acute methaemoglobinaemia due to ingestion of nitrobenzene (paint solvent). Indian J Anaesth. 2010;54:160-2.

8. Nascimento TS, Pereira RO, de Mello HL, Costa J Methemoglobinemia: from diagnosis to treatment. Rev Bras Anestesiol 2008;58:651-64.

9. Friedman BW, Corbo J, Lipton RB, et al. A trial of metoclopramide vs sumatriptan for the emergency department treatment of migraines. Neurology 2005;64:463-8.

10. Jellish WS, Kartha V, Fluder E, Slogoff S. Effect of metoclopramide on gastric fluid volumes in diabetic patients who have fasted before elective surgery. Anesthesiology
2005;102:904-9.

11. Hultquist DE. Cytochrome b5 reductase deficiency and enzymatic hereditary methemoglobinemia. In: Scriver CR, Beau$\operatorname{det} \mathrm{Al}$, Sly Ws, Valle D, editors. The metabolic and molecular basis of inherited disease. New York: McGraw-Hill; 1995.

12. Griffin JP. Methaemoglobinaemia. Adv Drug React Toxicol Rev 1997;16:45-63.

13. Descamps IM, Gressier B, Glowacki M, et al. Neonatal methaemoglobinemia and metoclopramide: case report. Therapie 2009; 64:67-9.

14. Mérieau E, Suc AL, Beau-Salinas F, Norbert K, Saliba E, Cantagrel S. Metoclopramide and neonatal methaemoglobinemia Arch Pediatr 2005;12:438-41.

15. Gregory L. Kearns, Debra H. Metoclopramide-induced methemoglobinemia. Pediatrics 1988;82:364-6.

16. Karadsheh NS, Shaker Q, Ratroat B. Metoclopramide-induced methemoglobinemia in a patient with co-existing deficiency of glucose-6-phosphate dehydrogenase and NADH-cytochrome b5 reductase: failure of methylene bluetreatment Haematologica 2001;86:659-60.

17. Grant SC, Close JR, Bray CL. Methaemoglobinaemia produced by metoclopramide in an adult. Eur J Clin Pharmacol 1994;47:89.

18. Mary AM, Bhupalam L J. Metoclopramide-induced methemoglobinemia in an adult. J Ky Med Assoc 2000;98:245-7. 